TRANSACTIONS OF THE

AMERICAN MATHEMATICAL SOCIETY

Volume 357, Number 2, Page 793

S 0002-9947(04)03509-3

Article electronically published on July 16, 2004

\title{
A NOTE ON THE HYPERBOLIC 4-ORBIFOLD OF MINIMAL VOLUME
}

\author{
RUTH KELLERHALS
}

Abstract. Paper withdrawn by author after original posting date of July 16, 2004 and prior to preparation of the printed issue.

Department of Mathematics, University of Fribourg, CH-1700 Fribourg, SwitzerLAND

E-mail address: Ruth.Kellerhals@unifr.ch

Received by the editors July 29, 2003 and, in revised form, September 17, 2003.

(C)2004 American Mathematical Society 